\title{
Archeological and mtDNA evidence for Tropical Lowland migrations during the Late Archaic / Formative in northern Chile
}

\author{
Evidencia arqueológica y de ADNmt para migraciones de Tierras Bajas Tropicales Durante \\ el Arcaico Tardío/Formativo Temprano en el norte de Chile
}

\author{
FRANCISCO ROTHHAMMER ${ }^{1,3,{ }^{*}, \text { CALOGERO M. SANTORO }}{ }^{1,4}$, ELIE POULIN $^{2}$, BERNARDO T. ARRIAZA $^{1,4}$ \\ MAURICIO MORAGA ${ }^{3} \&$ VIVIEN J. STANDEN ${ }^{4}$ \\ ${ }^{1}$ Instituto Alta Investigación, Universidad de Tarapacá, Arica, Chile \\ ${ }^{2}$ Instituto de Ecología y Biodiversidad, Departamento de Ecología, Facultad de Ciencias, Universidad de Chile, \\ Santiago, Chile \\ ${ }^{3}$ Programa de Genética Humana, ICBM - Facultad de Medicina, Universidad de Chile, Santiago, Chile \\ ${ }^{4}$ Departamento de Antropología, Universidad de Tarapacá, Arica, Chile \\ *Corresponding author: frothham@med.uchile.cl
}

\begin{abstract}
RESUMEN
La influencia de migraciones desde las tierras bajas tropicales en la emergencia de cambios culturales en los Andes Centrales, ha sido propuesta en términos generales desde comienzos de la última década (Tello 1929). Evidencia arqueológica y genético molecular reciente, particularmente la agricultura de cultígenos tropicales y la haplotipificacion de ADNmt antiguo, obtenida en el norte de Chile, sugieren una relación cronológicamente más acotada entre ambas regiones. Contrastamos en este artículo la hipótesis que el proceso de transformación cultural de las poblaciones prehistóricas costeras y vallunas del norte de Chile podría explicarse parcialmente por flujos migracionales originados en la vertiente oriental de los Andes y/o en las tierras bajas tropicales durante el periodo Arcaico Tardío / Formativo Temprano (ca. 3,500-2,000 A.P.).
\end{abstract}

Palabras clave: ADNmt antiguo, Andes Centrales, cambio cultural, foresta tropical, migración.

\begin{abstract}
The influence of tropical lowland migrations on the emergence of cultural change in the Central Andes has been postulated in general terms since the beginning of last century (Tello 1929). Archeological and molecular genetic evidence, particularly agriculture of tropical cultigens and ancient mtDNA haplogroup typing in northern Chile, suggest a chronologically more precise relationship between both regions. We test in this article the hypothesis that the process of cultural transformation of prehistoric populations living on the coast and the desert valleys of northern Chile can be partially linked to gene flow from the eastern slopes of the Andes and/or from the tropical lowlands during the Late Archaic / Formative periods (ca. 3,500-2,000 B.P.).
\end{abstract}

Key words: ancient mtDNA, Central Andes, cultural change, tropical lowland migration.

\section{INTRODUCTION}

The influence of lowland migrations on the emergence of cultural complexity in the Central Andes was initially postulated in general terms by Tello (1929) and more specifically by Lathrap (1970). Conversely, Meggers et al. (1965) claimed that cultural elements of the South American Formative period would have spread toward the south across the Andes, starting from the Ecuadorian coastline. The axis of interpretations changed again after the publication of the archeological evidences of Wankarani and Chiripa, Formative sites located south of Lake Titicaca (Ponce Sanjinés, 1970), and the circum-Titicaca area came to be the nucleus from which novel cultural developments of this period emerged. Thus, it was assumed that highland political and ideological principles, became integrated into a cultural strata of millenary coastal traditions (Núñez 1972, 1994, 1999, Muñoz 1989, Santoro 1980). 
In fact, during the fourth and third millennium B.P., important cultural changes in economic systems, political organization and ideological principles occurred, materialized in the installation of sedentary settlements within valleys or ravines in marshy or oasis-like environments close to the coast. Interestingly, settlements surrounded by graveyards and tumuli and early monumental ceremonial centers such as Chiripa (ca. B.P. 2,800-3,000) are also found in the circum-Titicaca area (Romero et al. 2004, Hastorf et al. 2001). Proposals for explaining sociocultural changes on the coast included highland migratory currents which had supposedly arrived in the valleys by means of vertically structured mechanisms of colonization, replacing the old hunting - gathering tradition (Rivera 1975, Rivera \& Rothhammer 1986) and less invasive migratory fluxes derived from demographic pressures generated in the circum-Titicaca region (Chacama 2001, Muñoz 1989, Núñez 1989, Santoro 2000).

On the basis of bioanthropological, particularly genetic and craniometrical, information available in the 1980 s the cultural development of some archaic coastal populations had been linked by our group to the tropical forest (Rivera \& Rothhammer 1986, Rothhammer \& Silva 1989, Rivera \& Rothhammer 1991, Rothhammer \& Silva 1992). The application of novel methodological approaches to cranial morphological analysis and preliminary ancient mtDNA data, allowed us later to identify a chronologically more precise relation (Moraga et al. 2001, Varela \& Cocilovo 2002, Rothhammer et al. 2002, Rothhammer et al. 2003, Varela et al. 2006).

The object of this article is to explore further this possible migrational link between coast and tropical lowlands, adding to the discussing recent bioarqueological evidence such as tropical agricultural products and molecular genetic data, particularly mtDNA.

\section{METHODS}

\section{Ancient and extant mtDNA samples}

Ancient mtDNA was extracted from skeletal remains exhumed in the archeological sites of Morro 1 and 1-6D, located at the outlet of the
Azapa Valley and dated with ${ }^{14} \mathrm{C}$ between 4,300 and 3,600 B.P. (Arriaza 2003). Furthermore, samples from the following archeological sites: Pircas-2, Caserones Sur, Tarapacá-40A and Tarapacá-0 (Tarapacá Valley) dated with ${ }^{14} \mathrm{C}$ between 3,790 and 1,350 B.P. were also analyzed (Moraga et al. 2005, Núñez 1982). The sites of Morro 1 and Morro 1-6 D belong to the Chinchorro Culture and are Late Archaic (Standen \& Santoro 2004, Moraga et al. 2005), whereas the sites located in the Tarapacá Valley, are Formative (Núñez 1982).

As known, the mtDNA from $95 \%$ of contemporary Amerindians falls within four maternal groups stemming from related lineages. These so called haplogroups are defined by a specific mtDNA marker. Haplogroup A is defined by the gain of a restriction site for the enzyme Hae III in the position 663, haplogroup B, by the deletion of $9 \mathrm{bp}$ in the intergenic region COII/tRNALys, haplogroup $\mathrm{C}$, by the loss of a site for the enzyme Hinc II in the position 13,259 and, finally, haplogroup D by the loss of a site for the enzyme Alu I in the position 5,176 (Schurr et al. 1990, Torroni et al. 1992, Wallace \& Torroni 1992). Other founding lineages have been postulated in extant and prehistoric aboriginal populations (Baillet et al. 1994, Easton et al. 1996, Stone \& Stoneking 1993; 1998, Ribeiro-dos-Santos et al. 1996).

DNA extraction and contamination precautions are described in Moraga et al. (2005). For comparative purposes we incorporated published mtDNA haplogroup frequencies from the archeological site of Tiwanaku, Bolivia dated at 1,400 B.P. (Rothhammer et al. 2003), the tropical forest, dated 4,000-500 B.P. (Ribeiro-Dos-Santos et al. 1996), the Lluta, Azapa and Camarones Valleys dated 1,650-500 B.P. (Moraga et al. 2005) and extant samples from Aymara, Atacameño and Quechua populations inhabiting the Central Andean region (Moraga 2001) (Table 1).

\section{Population genetic analyses}

Correspondence factor analysis was performed on the haplogroup contingency table using Genetix software (Belkhir et al. 2001) and employed as an exploratory tool to evaluate the genetic similarity/dissimilarity among samples. 
An unrooted neighbor-joining tree was constructed from a matrix of pairwise FST (coancestry distances) with the GDA software (Lewis \& Zaykin 2001). In order to estimate and compare haplotype frequencies among samples the Arlequin 3.11 program (Excoffier et al. 2005) was utilized. Random distribution hypotheses of the 4 haplogroups among pairwise samples were tested using permutation tests on Weir \& Cockerham (1984) pairwise $\mathrm{F}_{\mathrm{ST}}$. A two-level hierarchical analysis of molecular variance (AMOVA) was conducted on 4 groups determined by FCA analysis: [Chinchorro, Tiwanaku (Tiwan), Quechua], [Alto Ramirez (AltoR), Amazonia (Amazo)], [Cabuza-Maitas (CabMai), Late Alto Ramírez (LAltoR)] and [Atacameño (Ataca), Aymara, Gentilar-Inca (GenInc)]. Total genetic variance was partitioned in among group, among populations within groups and within population components. F-statistics based on haplogroup frequency differences were calculated among all samples (Fst), among samples within groups (Fsc) and among groups (Fct). A non-parametric permutation procedure was used to test whether statistics were significantly different from zero as implemented in Arlequin software.

\section{RESULTS}

Examination of haplogroup distribution of the skeletal material included in the analysis indicates that $\mathrm{B}$ and $\mathrm{C}$ haplogroups are the most frequent, followed by $\mathrm{A}$ and, at a much lower frequency, D (Table 1). Factorial correspondence analysis on haplogroup frequencies (Fig. 1) revealed four distinct clusters, namely [Chinchorro, Tiwan, Quechua], [AltoR, Amazo], [CabMai, LAltoR] and [Ataca, Aymara, GenInc]. First factorial component (61\% of the total genetic variation) clearly separated [AltoR, Amazo] and [Ataca, Aymara, GenInc] from the other samples. Among them, the second factorial component (29\% of the total genetic variation) separated [Chinchorro, Tiwan, Quechua] and [CabMai, LAltoR].

Unrooted neighbour-joining dendrogram (Fig. 2) also strongly grouped Ataca, Aymara, GenInc samples, as well as AltoR with Amazo. Furthermore, the first cluster of the dendrogram included, beside Alto Ramírez (Tarapacá Valley Formative) and Amazonia, also Tiwanaku, whereas the second cluster the Chinchorro fishermen (Late Archaic), most Azapa Valley prehistoric groups and extant Atacameño and Aymara samples from the Central Andes. The Quechua constitute a separate group. It is notewortly that populations included in cluster I exhibit on the average higher frequencies of $\mathrm{B}$, whereas cluster II groups, higher frequencies of haplogroups A and $\mathrm{D}$.

Most of pairwise exact tests were not statistically significant, probably because of small sample sizes. Only comparisons including Aymara $(\mathrm{n}=172)$ or Atacameño $(\mathrm{n}=$ 77) populations exhibited deviations from a random distribution of haplogroups. However, and despite the large sample size of both contemporary samples, Aymara and Atacameño populations did not exhibit statistically or

TABLE 1

Amerindian haplogroup relative frequencies for ten populations included in the analysis.

Frecuencias relativas de haplogrupos Amerindios para diez poblaciones incluidas en el análisis

\begin{tabular}{|c|c|c|c|c|c|c|c|c|c|c|}
\hline \multirow{2}{*}{$\begin{array}{l}\text { Locus } \\
\text { Haplo }\end{array}$} & \multicolumn{10}{|c|}{ Population } \\
\hline & 1 & 2 & 3 & 4 & 5 & 6 & 7 & 8 & 9 & 10 \\
\hline$(\mathrm{N})$ & 15 & 7 & 7 & 12 & 15 & 11 & 9 & 19 & 77 & 172 \\
\hline A & 0.3333 & 0.4286 & 0.2857 & 0.3333 & 0.2000 & 0.4545 & 0.1111 & 0.2632 & 0.1558 & 0.0698 \\
\hline B & 0.3333 & 0.1429 & 0.4286 & 0.4167 & 0.5333 & 0.0909 & 0.2222 & 0.3684 & 0.6883 & 0.6802 \\
\hline $\mathrm{C}$ & 0.0667 & 0.2857 & 0.2857 & 0.2500 & 0.2000 & 0.3636 & 0.3333 & 0.0526 & 0.1169 & 0.1221 \\
\hline $\mathrm{D}$ & 0.2667 & 0.1429 & 0.0000 & 0.0000 & 0.0667 & 0.0909 & 0.3333 & 0.3158 & 0.0390 & 0.1279 \\
\hline
\end{tabular}

Nota: (1) Chinchorro; (2) AltoR; (3) LAltoR; (4) CabMai; (5) GenInc; (6) Amazo; (7) Tiwan; (8) Quechua; (9) Ataca; (10) Aymara. 


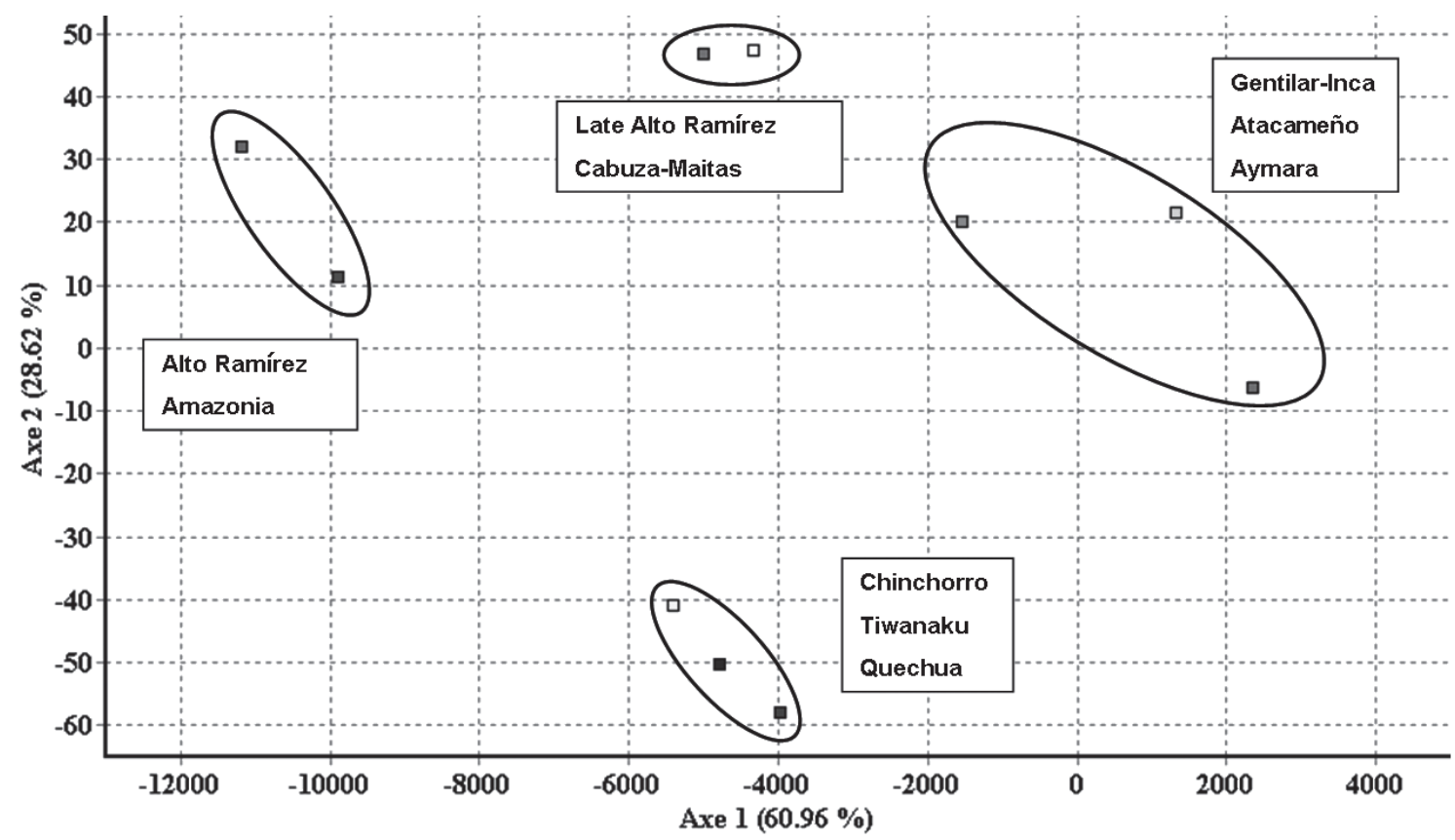

Fig. 1: Factorial Correspondence Analysis (FCA) plot.

Trazado del análisis factorial de correspondencia.

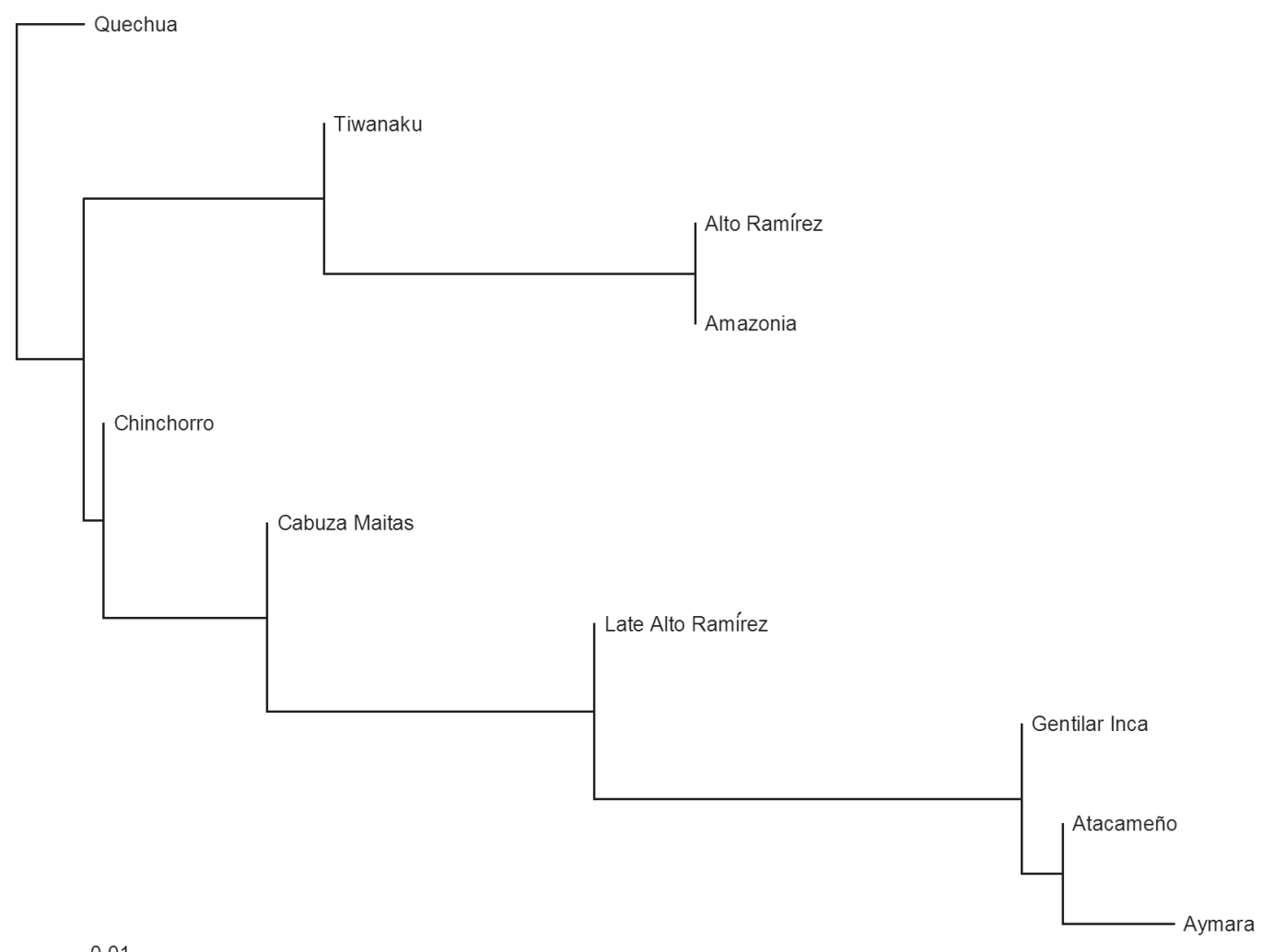

Fig. 2: Neighbor-joining unrooted tree constructed using pairwise F.

Árbol sin raíz construido a partir del método de unión de pares de valores F vecinos. 
marginally statistically significant genetic difference between them, nor with GenInc and LAltoR. On the contrary, and despite small sample size of ancient DNA samples, significant genetic differences were found with Amazonian samples and GenInc, as well as Quechua samples. AMOVA (Table 3) revealed that although most of the genetic diversity was attributable to differences among individuals within populations $(85.03 \%)$, there was still a high level of variation among groups (15.66 $\%)$. On the contrary, no significant difference was found among populations within groups.

\section{DISCUSSION}

Archeologists have advocated the view that local populations of the coast and valleys of northern Chile, and possibly southern Peru, maintained a long cultural maritime tradition that was gradually changed, along with the emergence of a new way of life characterized by ideological principles associated to a mixed economy that combined coastal resources and agriculture. Population movements from the eastern slopes of the Andes and/or the tropical lowlands could have been responsible for the introduction of tropical agricultural products found on the Pacific coastline in Late Archaic and Early Formative sites (ca. 3,500-2,000 BP). We note that this was a period of cultural changes at a continental level, which implied population movements associated with an improvement in the conditions of humidity in relation to the Middle Holocene, characterized by long periods of drought. Prehistoric groups in this region handled the complementary cultivation of edible roots, such as cassava or yuca (Manihot esculenta Crantz) and sweet

TABLE 2

Pairwise FST values (below diagonal) and associated P-values (above diagonal) obtained after 10,000 permutations.

Pares de valores FST (bajo diagonal) y valores de P (sobre diagonal) después de 10,000 permutaciones.

\begin{tabular}{lcccccccccc}
\hline & Chinchorro & AltoR & LAltoR & CabMai & GenInc & Amazo & Tiwan & Quechua & Ataca & Aymara \\
\hline Chinchorro & - & -0.0354 & -0.01876 & 0.00100 & 0.01402 & 0.04971 & 0.00006 & -0.05678 & 0.13701 & 0.14282 \\
AltoR & 59.82 & - & -0.06944 & -0.04415 & 0.04520 & -0.12202 & -0.03819 & 0.01037 & 0.24259 & 0.26346 \\
LAltoR & 49.22 & 49.12 & - & -0.12432 & -0.09088 & -0.00937 & -0.00858 & 0.00923 & 0.03248 & 0.06971 \\
CabMai & 39.22 & 48.32 & 82.48 & - & -0.04965 & 0.01261 & 0.03785 & 0.03178 & 0.06663 & 0.10837 \\
GenInc & 29.32 & 27.46 & 89.78 & 68.12 & - & 0.11494 & 0.04301 & 0.02119 & -0.00764 & 0.01041 \\
Amazo & 20.10 & 87.52 & 40.58 & 31.94 & $* 7.38$ & - & 0.02778 & 0.09800 & 0.30545 & 0.32891 \\
Tiwan & 37.60 & 47.24 & 35.66 & 26.26 & 19.60 & 27.82 & - & 0.00009 & 0.21583 & 0.18681 \\
Quechua & 90.96 & 35.52 & 33.78 & 24.46 & 26.9 & $* 7.16$ & 42.9 & - & 0.12878 & 0.12048 \\
Ataca & $* * 0.72$ & $* * 0.96$ & 19.82 & $* 9.42$ & 48.68 & $* * 0.06$ & $* * 0.76$ & $* * 0.32$ & - & 0.00595 \\
Aymara & $* * 0.48$ & $* * 0.46$ & 14.90 & $* * 3.42$ & 24.28 & $* * 0.02$ & $* * 0.98$ & $* * 0.30$ & 18.20 & - \\
\hline
\end{tabular}

$*=\mathrm{P}<0.05 ; * * \mathrm{P}>0.01$

TABLE 3

Molecular variance analysis for the partitioning among groups and among populations within groups. $(* * *, \mathrm{P}<0.001)$.

Análisis molecular de varianza para la separación entre grupos y entre poblaciones dentro de grupos.

\begin{tabular}{|c|c|c|c|c|}
\hline \multirow[b]{2}{*}{ Source of variation } & \multirow[b]{2}{*}{ df } & \multicolumn{2}{|c|}{ Groups } & \multirow[b]{2}{*}{ Fixation Indices (P values) } \\
\hline & & Variance components & $\%$ Total variance & \\
\hline Among groups & 3 & 0.05167 & 15.66 & $\mathrm{~F}_{\mathrm{CT}}=0.157(\mathrm{P}=0.002)$ \\
\hline Among populations / Within groups & 6 & -0.00229 & -0.70 & $\mathrm{~F}_{\mathrm{SC}}=-0.70^{\mathrm{NS}}(\mathrm{P}=0.843)$ \\
\hline
\end{tabular}


potato (Ipomoea batatas Linn. Poir) among others (Table 4 ). Although the origin and time of introduction of these crops into the region is still under debate, indirect evidence shows that cassava was a basic food crop in the Amazonian lowlands toward the year 3,000 B.P. (Meggers 1973). Sweet potato, of South American origin, is cultivated in the Amazon basin, the eastern plains of Bolivia, the warm (yungas) and mesothermal Andean valleys at a height of 2,400 m. Cassava and achira (Canna edulis Ker) are typical plants of the tropical zone of South America. The first competes with corn and potatoes as a main food, while the roots of achira are used as potato substitutes (Cárdenas 1989).

Interestingly, the vegetable strata which compose the ceremonial tumuli which typically characterize a late stage of the Formative of the western valleys, present precisely these plants of origin (Focacci \& Erices 1972-73). Local wild weeds are added, such as pitcher plant (Tessaria absinthioides Hook. \& Arn. DC.), and cortadera (Cortaderia atacamensis $\mathrm{Ph}$ 1.) (Niemeyer \& Schiappacasse 1963). Furthermore, recent excavations in Tumulus 8 of San Miguel (Late Formative) located in the Azapa Valley, show the presence of cultivated plants such as achira, yuca, pallar (Phaseolus lunatus L.), bean (Phaseolus vulgaris L.), cotton (Gossypium barbadense L.) and pumpkin (Cucurbita pepo L.) in one of the vegetable layers that conform the tumulus (CV4). Also, sites, such as Camarones 15 (ca. 1,100 B.C.) exhibit evidence of Mucuna elliptica (Ruiz Lopez \& Pavon. DC) seeds and cassava together with other diagnostic elements such as feathers of tropical lowland birds (Fig. 3 ), and components of the hallucinogen complex (Romero et al. 2004).

As has been mentioned earlier, links between Chinchorro and the tropical forest, in the terms stated initially by Rivera (1975) were basically backed up by the early genetic and craniometrical data obtained in the 1980s. Also, the cultural traits presented as evidence for a relation between Chinchorro and the tropical forest, corresponded to elements linked to the Late Chinchorro in transition toward the Early Formative (Standen \& Santoro 2004). Consequently, cultural traits tend to prove that links with the lowlands are much more evident during the initial farming period.

The unrooted neighbour-joining dendrogram (Fig. 2) reveals (see Results) that cluster one (C1) includes the Alto Ramírez (Quebrada de Tarapacá Formative), Amazonia and Tiwanaku samples. The Chinchorro fishermen (Late

TABLE 4

List of dated tropical cultigens identified in archaeological sites of northern Chile.

Listado de cultígenos tropicales datados identificados en sitios arqueológicos del norte de Chile.

\begin{tabular}{|c|c|c|c|c|c|}
\hline Site & Lab number & $\begin{array}{l}\text { Radiocarbon } \\
\text { date B.P. }\end{array}$ & $\begin{array}{c}\text { Calibrated dating } \\
\text { (95.4\% probability) B.P. }\end{array}$ & Tropical cultigen & Reference \\
\hline La Capilla 1 & GaK 8778 & $3,670 \pm 160$ & $4,450-3,550$ & Sweet potatoes & Muñoz \& Chacama 1982 \\
\hline La Capilla 1 & I-11642 & $3,450 \pm 90$ & $3,930-3,470$ & Manioc & Muñoz \& Chacama 1982 \\
\hline Camarones 15 & GaK 5813 & $3,060 \pm 100$ & $3,500-2,950$ & Muсuma elliptica seeds & Rivera et al. 1974 \\
\hline Azapa 71 & I- 10,856 & $2,855 \pm 85$ & $3,220-2,770$ & Mucama elliptica seeds & Santoro 1980 \\
\hline Azapa 71 & I- 10,859 & $2,685 \pm 85$ & $3,050-2,450$ & Manioc & Santoro 1980 \\
\hline Azapa 71 & - & ca. $3,000-2,500$ & & Achira & Santoro 1980 \\
\hline \multirow[t]{4}{*}{ PML 7} & GaK 5812 & $2,480 \pm 100$ & $2,760-2,340$ & Manioc & Focacci 1974 \\
\hline & & & & Mucuma elliptica seeds & Focacci 1974 \\
\hline & & & & Achira & Erices 1975 \\
\hline & & & & Sweet potatoes & Erices 1975 \\
\hline \multirow[t]{2}{*}{ Azapa 14} & GaK 5815 & $2,360 \pm 90$ & $2,750-2,150$ & Manioc & Santoro 1980 \\
\hline & & & & Sweet potatoes & Santoro 1980 \\
\hline AZ-12 & - & ca. $2,500-1,900$ & & Sweet potatoes & Muñoz 1986 \\
\hline
\end{tabular}


Archaic) and Azapa Valley prehistoric groups cluster together with Atacameño and Aymara samples from the Central Andes (see cluster 2 (C2)). Prehistoric populations of $\mathrm{C} 1$ are characterized by relatively higher frequencies of haplogroups A and by lower frequencies of haplogroup B, which exhibits very high frequencies among the Aymara and Atacameño (C2). Archaeological evidence indicates that during the Formative, Quebrada de Tarapacá was peopled by small bands of immigrants from the southern highlands of Bolivia, close to Lake Poopo, as judged by the presence of ceramic fragments and other cultural traits linked to Wankarani, a culture which established itself in that region around 3,000 B.P. Ponce Sanjinés 1970). Interestingly, Wankarani predates Tiwanaku and has been related to Tropical Lowland sites. (PonceSanjinés 1970, Núñez 1982)

The origin of the Tiwanaku population, hypothesized previously on the basis of ethnohistorical information, was explored by our group using ancient mtDNA extracted from skeletal remains from the archaeological sites of Akapana, Chiji, Jawira, Mollo Kontu and Putuni kindly provided by Dr. Alan Kolata and collaborators (Kolata 1993, 2003). Eighteen samples were analyzed, of which 13 could be typed for Amerindian haplogroups. The frequency distribution of haplogroups (A: $8 \%$,
B: $15 \%$, C: $23 \%$, D: $23 \%$ and others $31 \%$ ) relates in our analysis the remains from Tiwanaku genetically to extant Amazonian populations. Although the number of analyzed Tiwanaku individuals is very small, we note that their B haplogroup frequency is significantly lower than the frequency that characterizes the Aymara $(\mathrm{P}=0.0156)$ (Rothhammer et al. 2003) (see also Table 1). Although the decline of Tiwanaku, around 900 B.P. has been attributed to climatic changes (Albarracin-Jordan 1996, Kolata 1993, Kolata et al. 1997), we note that ethnohistoric data point to a military conquest of the circumtiticaca region by the Aymara during the same time (Gisbert et al. 1987, see also Torero 2003).

Recently, we presented a detailed analysis of chronologic mtDNA variation in the desert valleys of northern Chile, with the object of reconstructing the microevolutionary history of prehistoric groups in the context of their interaction with socially more complex highland populations including Tiwanaku (Moraga et al. 2005). We obtained the following haplogroup distribution (A through D) for 19 individuals belonging to the Middle Period : $0.316,0.421,0.263$ and 0.0 . Lewis et al. (2007), addressing hypothesis concerning the origin of the Moquegua Valley Chen Chen site (A. D. 785-1,000), a Tiwanaku settlement

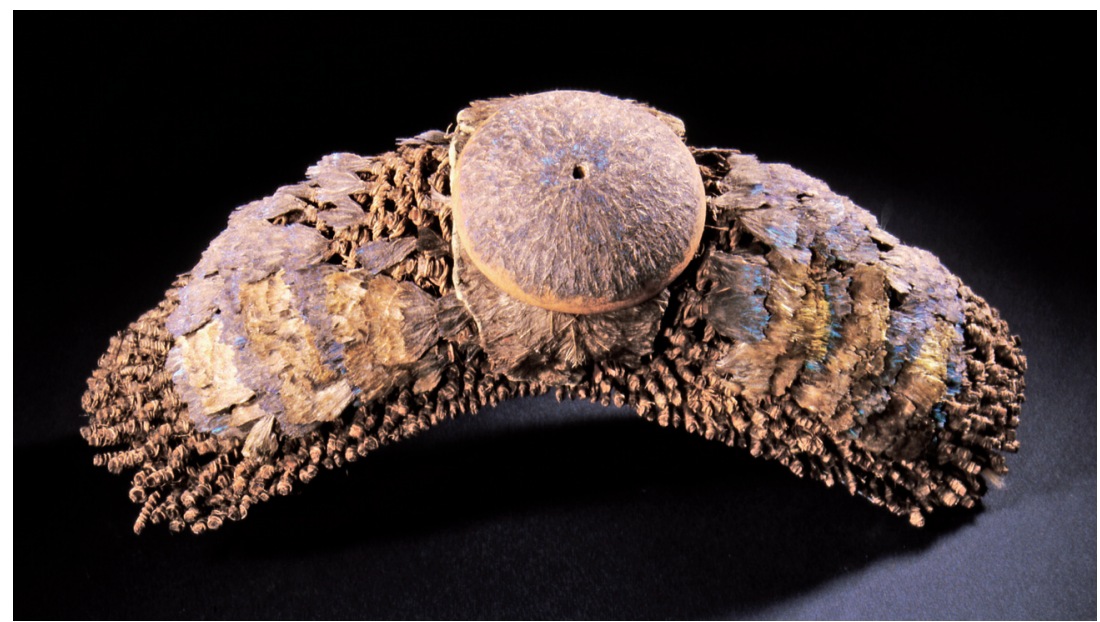

Fig. 3: Tropical feather headdress from Camarones 15 archeological site (Museo Arqueológico Universidad de Tarapacá San Miguel de Azapa, photo courtesy of Fernando Maldonado).

Tocado de plumas de aves tropicales sitio arqueológico Camarones 15 (Museo Arqueológico Universidad de Tarapacá, San Miguel de Azapa, foto cortesía de Fernando Maldonado). 
located close to the Chilean Azapa Valley in southern Peru, examined 27 informative skeletal samples obtaining the following $\mathrm{mt}$ DNA haplogroup frequency distribution (A through D): $0.391,0.391,0.741$ and 0.043 . These frequencies are similar to our Azapa Valley samples for the same archaeological period. Apart from the methodological implication of this finding, it suggests a genetic link between the prehistoric populations of both valleys. No doubt, the process of change of coastal societies also included technologies linked to the explotation of maritime resources from the southern coast of Perú which endured until late stages of regional prehistory.

Haplogroup B increases its frequencies progressively from the Middle Period (ca. 1,000 B.P.) to the Late Period in the Azapa Valley. In the case that this frequency change is not the result of stochastic microevolutionary phenomena, it could be interpreted as backing up archaeological evidence suggesting the arrival in Azapa Valley of the Aymara during the Middle Period.

Concluding, the simultaneous analysis of archaeological and mtDNA data revealed results, whose interpretation may contribute to a better understanding of the prehistoric population movements which had a bearing on the cultural changes that took place during the fourth and third millennium before present in northern Chile, the Bolivian Highlands and southern Perú.

\section{ACKNOWLEDGEMENTS:}

We gratefully acknowledge the support of grants Fondecyt (Number \# 1095006), CIHDE and Convenio de Desempeño UTA/ Mecesup-2.

\section{LITERATURE CITED}

ALBARRACIN-JORDAN J (1996) Tiwanaku. Arqueología regional y dinámica segmentaria. Plural Editores, La Paz. 393 pp.

ARRIAZA B (2003) Cultura Chinchorro las momias más antiguas del mundo. Editorial Universitaria, Santiago, Chile. 266 pp.

BAILLIET G, F ROTHHAMMER, F CARNESE, C BRAVI \& N BIANCHI (1994) Founder mitochondrial Haplotypes in American populations. American Journal of Human Genetics 55: 27-33.

BELKHIR K, P BORSA, L CHIKHI, N RAUFASTE \& F
BONHOMME (2001) GENETIX 4.02, logiciel sous Windows TM pour la génétique des populations. Laboratoire Génome, Populations, Interactions CNRS UMR 5000, Université de Montpellier II, Montpellier, France.

CÁRDENAS M (1989) Manual de plantas económicas de Bolivia. Segunda edición. Editorial Los Amigos del Libro, Cochabamba. 334 pp.

CHACAMA J \& I MUÑOZ (2001) El sitio Acha-2, extremo norte de Chile ca. 9,500 - 10,000 años A.P. Chungará Revista de Antropología Chilena 33: 51-54.

EASTON R, A MERRIWETHER, D CREWS \& $R$ FERRELL (1996) mtDNA variation in the Yanomami: Evidence for aditional New World founding lineages. American Journal of Human Genetics 59: 213-225.

ERICES S (1975) Evidencias de vegetales en tres cementerios prehispánicos, Arica - Chile. Chungará Revista de Antropología Chilena 5: 65-71.

EXCOFFIER L, G LAVAL \& S SCHNEIDER (2005) Arlequin ver. 3.0: An integrated software package for population genetics data analysis. Evolutionary Bioinformatics Online 1: 47-50.

FOCACCI G \& S ERICES (1972-1973) Excavaciones en túmulos de San Miguel de Azapa. Actas del IV Congreso de Arqueología Chilena: 47-55. Número especial, Universidad de Chile.

FOCACCI G (1974) Excavaciones en el cementerio Playa Millar 7. Chungará Revista de Antropología Chilena 3: $23-74$

GISBERT T, S ARZE \& M CAJÍAS (1987) Arte textil y mundo andino. Gisbert y Cía., La Paz. 312 pp.

HASTORF AC, MW BANDY, T WHITEHEAD \& L STEADMAN (2001) El periodo Formativo en Chiripa, Bolivia. Textos Antropológicos 13: 17-91.

KOLATA A (1993) The Tiwanaku: Portrait of an Andean Civilization. Blackwell, Cambridge. 317 pp.

KOLATA A, M BINFORD, M BRENNER, M ABBOTT, W JANUSEK, M SEDDON, \& J CURTIS (1997) Climate variation and the rise and fall of an Andean Civilization. Quarternary Research 47: 235-248.

KOLATA A (2003) Tiwanaku and its Hinterland: Archaeology and paleoecology of an Andean Civilization. Volume 2: Urban and rural archaeology. Smithsonian Institution Press, Washington DC. 544 pp.

LATHRAP DW (1970) The upper Amazon. Thames \& Hudson, Southampton. $256 \mathrm{pp}$.

LEWIS PO \& D ZAYKIN (2001) GDA (Genetic Data Analysis): Computer program for the analysis of allelic data. Version $1.0 \mathrm{~d} 16 \mathrm{c}$. University of Connecticut, Storrs, Connecticut.

LEWIS CM, BUIKSTRA JE \& STONE AC (2007) Ancient DNA and genetic continuity in the southcentral Andes. Latin American Antiquity 18: 145160.

MEGGERS JB, E CLIFFORD \& E ESTRADA (1965) Early formative period of coastal Ecuador. The Valdivia and Machalilla Phases. Smithsonian Contributions to Anthropology 1, Washington DC. $234 \mathrm{pp}$.

MEGGERS JB (1973) Some problems of cultural adaptation in amazonia, with emphasis on the preeuropean period. In: Meggers BJ, ES Ayensu \& WD Duckworth (eds) Tropical forest in Africa and South America: A comparative review: 311-320. Smithsonian lnstitution Press, Washington DC.

MORAGA M, E ASPILLAGA, MC SANTORO, GV STANDEN, P CARVALLO \& F ROTHHAMMER (2001) Análisis de ADN mitocondrial en momias 
del norte de Chile avala hipótesis de origen amazónico de poblaciones andinas. Revista Chilena de Historia Natural 74: 719-726.

MORAGA M, C SANTORO, V STANDEN, P CARVALLO \& F ROTHHAMMER (2005) Microevolution in prehistoric Andean populations: Chronologic mtDNA variation in the desert valleys of northern Chile. American Journal of Physical Anthropology 127: 170-181.

MUÑOZ I (1986) Aportes a la reconstitución histórica del poblamiento aldeano en el valle de Azapa (AricaChile). Chungará Revista de Antropología Chilena 16/17: 307-322

MUÑOZ I (1989) El período Formativo en el Norte Grande. In: Hidalgo J, V Schiappacasse, H Niemeyer, C Aldunate \& I Solimano (eds) Culturas de Chile. Prehistoria. Desde sus orígenes hasta los albores de la conquista: 107-128. Editorial Andrés Bello, Santiago, Chile.

MUÑOZ I \& J CHACAMA (1982) Investigaciones arqueológicas en las poblaciones precerámicas de la costa de Arica. Documento de Trabajo Universidad de Tarapacá 2: 3-97.

NIEMEYER H \& V SCHIAPPACASSE (1963) Investigaciones arqueológicas en las terrazas de Conanoxa, Valle de Camarones (Prov. de Tarapacá). Anales de la Academia Chilena de Ciencias (Chile) 26: 101-166.

NÚÑEZ L (1972) Sobre el comienzo de la agricultura prehistórica en el norte de Chile. Estudios arqueología andina. Centro de Investigaciones Arqueológicas en Tiwanaku 4: 1-24.

NÚÑEZ L (1982) Temprana emergencia de sedentarismo en el desierto chileno: proyecto Caserones. Chungará 9: 80-122.

NÚÑEZ L (1989) Hacia la producción de alimentos y la vida sedentaria (5,000 a.C a 900 d.C.). In: Hidalgo J, V Schiappacasse, H Niemeyer, C Aldunate \& I Solimano (eds) Culturas de Chile. Prehistoria. Desde sus orígenes hasta los albores de la conquista: 81-105. Editorial Andrés Bello, Santiago, Chile.

NÚÑEZ L (1994) The western part of South America (southern Peru, Bolivia, northwest Argentina and Chile) during the stone age. In: de Laet SJ (ed) History of Humanity Vol. 1: 348-302. Editorial UNESCO, París, Francia.

NÚÑEZ L (1999) Archaic adaptation on the South Central Andean Coast. In: Blake M (ed) Pacific Latin American in prehistoric: The evolution of archaic and formative cultures: 199-212. Washington State University Press, Washington DC.

PONCE-SANJINÉS C (1970) Wankarani y Chiripa y su relación con Tiwanaku. Academia Nacional de Ciencias de Bolivia. Publicación $\mathrm{N}^{\circ}$ 25, La Paz.

RIBEIRO-DOS-SANTOS A, K SIDNEY, L SANTOSMACHADO, A GUAPINDAIA, AM ZAGO (1996) Heterogeneity of mitochondrial DNA haplotypes in pre-Columbian natives of the Amazon region. American Journal of Physical Anthropology 101: 29-37.

RIVERA AM \& F ROTHHAMMER (1986) Evaluación biológica cultural de las poblaciones Chinchorro: nuevos elementos para la hipótesis de contactos transaltiplánicos, cuenca Amazonas-Costa Pacífico. Chungará Revista de Antropología Chilena 16/17: 295-306

RIVERA AM \& F ROTHHAMMER (1991) The Chinchorro people of northern Chile 5,000 BC-500
BC: A review of their culture and relationships. Journal of Human Evolution 3: 243-255.

RIVERA AM (1975) Una hipótesis sobre movimientos poblacionales altiplánicos y transaltiplánicos a las costas del norte de Chile. Chungará Revista de Antropología Chilena 5: 7-32

RIVERA AM, P SOTO \& D KUSHNER (1974) Aspecto sobre el desarrollo tecnológico en el proceso de agriculturización en el norte prehispánico especialmente Arica (Chile). Chungará Revista de Antropología Chilena 3: 79-107.

ROMERO A, C SANTORO, D VALENZUELA, J CHACAMA, E ROSELLO \& L PIACENZA (2004) Túmulos, ideología y paisaje de la fase Alto Ramírez del valle de Azapa. Chungará Revista Antropología Chilena Volumen Especial: 235-247.

ROTHHAMMER F \& C SILVA (1989) Peopling Andean South America. American Journal of Physical Anthropology 78: 403-410.

ROTHHAMMER F \& C SILVA (1992) Gene geography of South America: Testing models of populations displacement based on archaeological evidence. American Journal of Physical Anthropology 89: 441-446.

ROTHHAMMER F, M MORAGA, M RIVERA, C SANTORO, V STANDEN, F GARCÍA \& P CARVALLO (2003) Análisis de ADNmt de restos esqueletales del sitio Arqueológico de Tiwanaku y su Relación con el Origen de sus Constructores. Chungará Revista de Antropología Chilena 35: 269-274.

ROTHHAMMER F, C SANTORO \& M MORAGA (2002) Craniofacial chronological microdifferentiation of human prehistoric populations of the Azapa Valley, northern Chile. Revista Chilena de Historia Natural 75: 259-264.

SANTORO C (1980) Fase Azapa transición del arcaico al desarrollo agrario inicial en los valles bajos de Arica. Chungará Revista de Antropología Chilena 6: 45-56.

SANTORO C (2000) Formativo en la región de valles occidentales del área Centro Sur Andina. In: Lederberger P (ed) Formativo sudamericano, una revaluación: 243-254. Editorial Abya-Yala, Quito.

SCHURR TG, SW BALLINGER, YY GAN, JA HODGE, DA MERRIWETHER, DN LAWRENCE, WC KNOWLER (1990) Amerindian mitochondrial DNAs have rare Asian mutations at high frequencies suggesting they derived from four primary maternal lineages. American Journal of Human Genetics 46: 613-623.

STANDEN V \& C SANTORO (2004) Patrón funerario arcaico temprano del sitio Acha-3 y su relación con chinchorro: Cazadores pescadores y recolectores de la costa Norte de Chile. Latin American Antiquity 15: $89-109$

STONE A \& M STONEKING (1993) Ancient DNA a precolumbian Amerindian population. American Journal of Physical Anthropology 92: 463-471.

STONE A \& M STONEKING (1998) mtDNA analysis of a prehistoric Oneota population: Implications for the peopling of the New World. American Journal of Human Genetics 62: 1153-1170.

TELlO JC (1929). Antiguo Perú. I Epoca. Empresa Editora Excelsior, Lima. 183 pp.

TORERO A (2002) Idiomas de los Andes, lingüística e historia. Instituto Francés de Estudios Andinos, Editorial Horizonte, Lima. 565 pp.

TORRONI A, T SCHURR, Y CHI-CHUAN, E SZATHMARY, CW ROBERT, M SCHANFIELD, 
G TROUP, W KNOWLER, D LAWRENCE, K WEISS \& D WALLACE (1992) Native American mitochondrial DNA analysis indicated that the Amerind and the Nadene populations were founded by two independent migrations. Genetics 130: 153162.

VARELA H \& JA COCILOVO (2002) Genetic drift and gene flow in a prehistoric population of the Azapa Valley and Coast, Chile. American Journal of Physical Anthropology 118: 259-267.

VARELA H, JA COCILOVO, C SANTORO \& F

Associate Editor: Claudio Latorre

Received September 30, 2008; accepted August 26, 2009
ROTHHAMMER (2006) Microevolution of human archaic groups of Arica, northern Chile and its genetic contribution to populations from the formative period. Revista Chilena de Historia Natural 79: 185-193.

WALLACE D \& A TORRONI (1992) American Indian prehistory as written in the mitochondrial DNA: A review. Human Biology 64: 403-416.

WEIR BS \& C COCKERHAM (1984) Estimating Fstatistics for the analysis of population structure. Evolution 38: 1358-1370 